\title{
Association of College \& Research Libraries 2019: Recasting the Narrative
}

\author{
Yali Feng, University of Illinois at Urbana-Champaign, United States
}

Association of College \& Research Libraries (ACRL) holds the most prestigious conferences for academic and research libraries in the United States. ACRL 2019 was held April 10-13, 2019, in Cleveland, Ohio. About 3,000 attendees enjoyed more than 500 conference programs and had the chance to meet with representatives from more than 200 major companies.

ACRL had three keynote speakers, with core themes of "recasting the narrative" for justice and inclusiveness. The three keynote speakers were Michele Norris, Viet Thanh Nguyen, and Alison Bechdel.

- Michele Norris is a Peabody Award-winning journalist. She presented on two projects, The Race Card Project and The Bridge, which focused on race, identity, connectivity and inclusion.

- Viet Thanh Nguyen is a writer, author of The Sympathizer, and Pulitzer Prize winner. His speech powerfully advocated just representation of refugee voices and focused on the Vietnam War.

- Alison Bechdel is a cartoonist whose work is involved with "expanding the expressive potential of the graphic form". For that, she received the 2014 MacArthur "Genius" Grant. In her speech, Alison narrated her journey of exploring gender identity, which is deeply intertwined with her family history.

Overall, these three outstanding speakers exhibited their efforts of exploring the same goal: finding a better approach to reach peace and happiness, with different angles at different levels.

The ACRL 2019 Proceedings included 12 tracks with corresponding session numbers listed in brackets: Administration, management, and leadership (15), Assessment (12), Collection (4), Outreach (8), Professional/Staff Development (8), Reference (3), Scholarly Communication (9), Special Collections/Archives (1), Teaching and Learning (24), Technical Services (2), and Technology and Tools (2). The track of Teaching and Learning received the most conference attention.

There were several themes that caught my attention. First, there was an overarching focus on the importance of diversity and social justice, as reflected by keynote speakers and throughout the conference. Secondly, I was surprised by the interesting attention to emotions and mental health in the library context, which were explored broadly in presentations, posters, roundtables, and panel discussions. Emotion management, emotional labor, emotional intelligence, and the importance of empathy all were considered from multiple perspectives. We can expect more discussion and debates on such topics as stress and confusion increases with incoming AI 
applications and more unfolding diversity issues. The publishers and libraries and their workers are trying to find an anchor for this incoming technology wave. Thirdly, a focus on various aspects of data was one of the threads in the conference, especially with respect to how to respond to emerging data science. Topics such as research data management and sharing, data skill building and application, continuing digitization of physical sources, and recasting the narrative with data through breaking disciplinary boundaries were among the data related topics that received considerable attention.

For further detail, please refer to ACRL 2019 website (https://conference.acrl.org/).

\section{References}

https://conference.acrl.org/

http://www.ala.org/acrl/conferences/acrl2019/papers

https://sr.ithaka.org/blog/what-to-watch-for-at-acrl-2019-research-data-edition/ 